\title{
Efektivitas Sistem Informasi Akuntansi, Budaya Organisasi dan Kinerja Karyawan di Lembaga Perkreditan Desa Kecamatan Tegalalang
}

\author{
I Gusti Ngurah Krisna Dwipayana' ${ }^{1}$ \\ Fakultas Ekonomi dan Bisnis \\ Universitas Udayana, Indonesia
}

\author{
I Dewa Gede Dharma Suputra ${ }^{2}$ \\ Fakultas Ekonomi dan Bisnis \\ Universitas Udayana, Indonesia
}

\begin{abstract}
Surel : krismon336@gmail.com
ABSTRAK

Kinerja karyawan merupakan suatu tingkat keberhasilan seseorang secara keseluruhan dalam melaksanakan suatu tugas. Kinerja karyawan yang baik di dorong oleh efektivitas sistem informasi akuntansi dan budaya organisasi. Tujuan penelitian ini adalah untuk memberikan bukti empiris pengaruh efektivitas sistem informasi akuntansi dan budaya organisasi pada kinerja karyawan. Penelitian ini dilakukan di Lembaga Perkreditan Desa Se-Kecamatan Tegalalang. Jumlah responden yang diambil sebanyak 121 orang pegawai, dengan metode purposive sampling. Pengumpulan data dilakukan menggunakan kuesioner. Teknik analisis yang digunakan adalah regresi linear berganda. Hasil penelitian menunjukan bahwa efektivitas sistem informasi akuntansi dan budaya organisasi berpengaruh positif pada kinerja karyawan.
\end{abstract}

Kata Kunci: Efektivitas Sistem Informasi Akuntansi; Budaya Organisasi; Kinerja Karyawan.

The Effectiveness of Accounting Information Systems, Organizational Culture and Employee Performance at the Village Credit Institution, Tegalalang District

\section{ABSTRACT}

Employee performance is a level of overall success for a person in carrying out a task. Good employee performance is driven by the effectiveness of the accounting information system and organizational culture. The purpose of this study was to provide empirical evidence in the effect of the effectiveness of accounting information systems and organizational culture on employee performance. This research conducted at the Village Credit Institutions in Tegalalang District. The number of respondent taken was 121 employees, with a purposive sampling method. Data collection was carried out using a questionnaire. The analysis technique used is multiple linear regression. The results showed that the effectiveness of the accounting information system and organizational culture had a positive effect on employee performance.

Keywords: Effectiveness of Accounting Information Systems; Organizational Culture; Employee Performance.

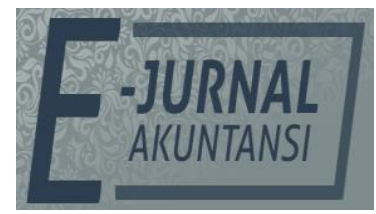

e-ISSN 2302-8556

Vol. 31 No. 2

Denpasar, Februari 2021 Hal. 298-308

DOI:

10.24843/EJA.2021.v31.i02.p03

PENGUTIPAN:

Dwipayana, I G.N.K., \& Suputra, I D.G.D. (2021). Efektivitas Sistem Informasi Akuntansi, Budaya Organisasi dan Kinerja Karyawan di Lembaga Perkreditan Desa Kecamatan Tegalalang. E-Jurnal Akuntansi, 31(2), 298-308

RIWAYAT ARTIKEL:

Artikel Masuk: 20 Agustus 2020 Artikel Diterima: 28 Desember 2020

Artikel dapat diakses : https://ojs.unud.ac.id/index.php/Akuntansi/index 


\section{PENDAHULUAN}

Teknologi informasi sangatlah dibutuhkan dalam berbagai bidang tak terkecuali dengan akuntansi. Kelton et al. (2007) menyatakan bahwa perkembangan pesat teknologi informasi akan memberikan dampak yang positif dan signifikan bagi perusahaan, dimana kelangsungan hidup perusahaan ditentukan oleh kemampuan bersaingnya, dan kemampuan bersaing memerlukan strategi dengan memanfaatkan berbagai kekuatan dan peluang yang dimiliki serta menutup kelemahan dan hambatan strategis yang dihadapi untuk meningkatkan efektivitas pengelolaan perusahaan, penting untuk memiliki informasi akuntansi yang berkualitas karena data dan informasi tersebut akan menjadi dasar pengambilan keputusan (Nwokeji, 2012).

Tujuan utama akuntansi adalah menyediakan informasi yang diperlukan oleh para pemangku kepentingan untuk pengambilan keputusan. Hal ini menyebabkan sistem informasi memiliki peranan penting di bidang akuntansi. Secara umum, semua perusahaan akan selalu membutuhkan suatu informasi sebagai bahan pertimbangan dalam pengambilan keputusan. Oleh karena itu, informasi yang tersedia harus merupakan informasi yang akurat, tepat waktu, dan relevan (Larasdiputra \& Suryanawa, 2014). Informasi juga diharapkan mampu meningkatkan efektivitas sistem yang digunakan dalam perusahaan, di mana efektivitas dalam hal ini terkait dengan ukuran yang dapat menggambarkan seberapa jauh target dapat dicapai, baik secara kualitas maupun kuantitas, dengan berorientasi pada keluaran (output) yang dihasilkan (Yamit, 2003). Suatu sistem dapat dikatakan efektif apabila mampu menghasilkan informasi yang berkualitas, sehingga informasi tersebut dapat meningkatkan pula kinerja perusahaan.

Sistem Informasi akuntansi (SIA) adalah komponen - komponen yang saling berhubungan yang terintegrasi untuk mengumpulkan, menyimpan, dan menyebarkan data untuk tujuan perencanaan, pengendalian, koordinasi, analisis, dan pengambilan keputusan (Soudani, 2012). Sistem Informasi memiliki peranan yang sangat penting dalam bidang akutansi, karena pada dasarnya tujuan utama akuntansi adalah menyediakan informasi untuk para pemgambil keputusan. Secara umum semua perusahaan atau organisasi akan selalu membutuhkan informasi untuk mengambil suatu keputusan.

Sistem informasi akuntansi dianggap sebagai faktor penting dalam pencapaian kinerja yang lebih besar terutama dalam proses pengambilan keputusan (Ariyanto et al., 2020) dan (Candraningrat et al., 2020). Sistem Informasi Akuntansi (SIA) dapat menambah nilai bagi suatu perusahaan dengan menghasilkan informasi yang akurat dan tepat waktu (Al-Eqab \& Adel, 2013). Fungsi utama dari sistem informasi akuntansi adalah memproduksi informasi berdasarkan data yang merupakan hasil dari transaksi keuangan (Tokic et al., 2011). Sistem informasi akuntansi merupakan suatu sistem yang berada di bidang teknologi akuntansi, untuk membantu pengelolaan, pengendalian data dan informasi terkait bidang ekonomi dan keuangan (Grande et al., 2011). Pentingnya penggunaan SIA dalam menghasilkan informasi yang berkualitas dan mendukung proses pengambilan keputusan dapat meningkatkan efisiensi organisasi (Apriada \& Suardikha, 2016). 
Hal ini mempengaruhi kinerja karyawan dan meningkatkan efektivitas organisasi salah satu faktornya berasal dari budaya organisasi (Brahmasari \& Siregar, 2009). Budaya organisasi dapat dikatakan kuat jika antar karyawan mempunyai nilai-nilai bersama yang dianggap baik dan sesuai dengan ketentuan. Semakin banyak nilai saling berbagi dan saling menerimanya maka akan semakin memperkuat budaya yang diterapkan sebuah organisasi dalam berperilaku (Ivancevich, 2007). Tanpa adanya budaya yang mendorong untuk saling percaya antara rekan kerja, bersedia untuk berbagi pengetahuan, maka kinerja organisasi tidak akan berkembang bahkan tidak dapat bertahan dalam dalam berbagai kondisi (Kusumadmo, 2013). Budaya organisasi dapat menjadi instrumen keunggulan dalam bersaing yang utama apabila budaya tersebut dapat mendukung strategi organisasi, mampu menjawab dan mengatasi tantangan persaingan maupun perubahan yang terjadi dengan tepat dan tanggap (Soedjono, 2005). Setiap perusahaan memiliki tipe budaya organisasi yang berbeda antara satu perusahaan dengan perusahaan lainya. Selain itu budaya organisasi juga dijadikan sebagai media dalam membentuk hubungan antara karyawan dengan organisassi tersebut. Berdasarkan hal itu karyawan akan merasa bahwa mereka merupakan bagian dari organisasi (Tanuwibowo \& Sutanto, 2014).

Budaya organisasi merupakan keyakinan, nilai-nilai, sikap maupun etika yang menjadi pedoman. Sehingga budaya organisasi dapat dijadikan untuk mengawasi pegawai mulai dari cara bekerja sama maupun dasar seluruh anggota organisasi untuk menjalankan pekerjaannya. Selain itu budaya organisasi merupakan cara berinteraksi antara karyawan satu dengan yang lainnya. Jika budaya organisasi yang diterapkan baik maka akan berakibat baik pula terhadap kinerja yang dihasilkan terhadap peruasahaan (Arianty, 2014). "A system of shared meaning held by members that distinguishes the organization from other organization" yang berarti bahwa budaya organisasi merupakan sistem atau makna yang dilakukan oleh anggota organisasi untuk membedakan dengan organisasi lain (Robbins \& Judge, 2011). Organisasi yang mengutamakan profit dengan yang tidak mengutamakan profit akan memiliki budaya organisasi yang berbeda pula. Begitu juga organisasi kampus dengan organisasi di perusahaan, mereka mempunyai cara mereka tersendiri untuk mencapai tujuannya. Organisasi kampus akan cenderung mengambil keputusan berdasarkan musyawarah, sedangkan organisasi perusahaan mengambil keputusan berdasarkan hierarki kedudukan. Budaya organisasi yang diterapkan secara tepat pada tipe organisasi tertentu akan mampu meningkatkan kinerja karyawan maupun pengambilan suatu keputusan.

Berdasarkan penelitian yang dilakukan oleh Tanuwibowo \& Sutanto (2014) menyatakan bahwa budaya organisasi berpengaruh secara signifikan terhadap kinerja pegawai pada PT. Tirta Sarana Sukses. Hasil penelitian yang dilakukan oleh Afnita et al. (2014) menyatakan bahwa terdapat hubungan yang signifikan antara budaya organisasi dengan kinerja pegawai. Begitu juga dengan penelitian Shahzad et al. (2014) menyatakan bahwa budaya organisasi berpengaruh terhadap kinerja karyawan.

Lembaga Perkreditan Desa (LPD) merupakan lembaga keuangan milik desa pekraman yang telah berkembang dan telah memberi manfaat sosial, 
ekonomi dan budaya kepada anggotanya. Sehingga perlu dibina, ditingkatkan kinerjanya, dan di perkuat serta dilestarikan keberadaannya (Suartana, 2009). LPD merupakan pilihan utama bagi masyarakat untuk mendapatkan pinjaman dana dengan prosedur yang mudah. Keberadaan LPD memberikan dampak sosial dimana LPD diwajibkan memberi 20 persen keuntungannya untuk dana pembangunan desa, 5 persen dana pemberdayaan, dan 5 persen dana sosial (Peraturan Gubernur Bali Nomor 44 Tahun 2017, Pasal 85).

Tabel 1. Perkembangan Aset LPD Kecamatan Tegallalang Tahun 2014-2018

\begin{tabular}{ccc}
\hline No & Tahun & Aset \\
\hline 1 & 2014 & $\operatorname{Rp~368.573.916.000~}$ \\
2 & 2015 & $\operatorname{Rp~432.923.999.000~}$ \\
3 & 2016 & $\operatorname{Rp~491.434.073.000~}$ \\
4 & 2017 & $\operatorname{Rp} 541.426 .997 .000$ \\
5 & 2018 & $\operatorname{Rp~611.082.893.000~}$
\end{tabular}

Sumber: LPLPD Kabupaten Gianyar, 2018

Berdasarkan penelitian sebelumnya yang mencantumkan aset LPD SeKecamatan Tegalalang dan didukung data pada Tabel 1, dapat dilihat bahwa tingkat aset LPD mengalami peningkatan setiap tahunnya. Hal ini mengindikasikan bahwa partisipasi masyarakat terhadap LPD meningkat. Jumlah aset yang besar sangat rentan dengan adanya kecurangan yang dilakukan oleh pihak yang memiliki kepentingan. Dengan jumlah aset yang besar ini dibutuhkannya suatu sistem informasi akuntansi yang dapat mempermudah pengolahan data pada LPD. Lembaga Perkreditan Desa SeKecamatan tegalalang sebagian besar telah menerapkan sistem informansi akuntansi berbasis komputer dalam pengolohan datanya, namun peneliti masih melihat kinerja karyawan yang belum efektif karena belum mahir mengoperasikan SIA yang ada. Berdasarkan Peraturan Gubernur Bali Nomor 44 Tahun 2017, Pasal 37 ayat (1) yang menyebutkan bahwa pengurus dan pemeriksa LPD dipilih, diangkat, dan diberhentikan melalui Paruman Adat. Hal tersebut berarti karyawan yang bekerja di LPD dipilih melalui paruman di Desa Adat yang mengutamakan musyawarah dan mufakat dibanding melihat latarbelakang pendidikan yang mengakibatkan pegawai kurang mengerti tentang pekerjaannya dan belum memiliki skill yang baik. LPD di Kecamatan Tegalalang ditinjau dari besarnya aset, menunjukan bahwa LPD tersebut telah semakin berkembang.

Penelitian ini menguji pengaruh variabel efektivitas SIA dan budaya organisasi pada variabel kinerja karyawan. Penelitian yang mengangkat permasalahan pengaruh efektivitas sistem informasi akuntansi dan budaya organisasi terhadap kinerja karyawan telah banyak dilakukan pada penelitianpenelitian sebelumnya, tetapi hasil yang diperoleh tidak selalu konsisten. Hasil penelitian Marlinawati \& Suaryana (2013), Mercika \& Jati (2015), Puja \& Suardikha (2013), dan Astuti \& Dharmadiaksa (2014) menunjukkan bahwa efektivitas sistem informasi akuntansi berpengaruh positif signifikan terhadap kinerja individu dan karyawan. Namun, hasil berbeda diperoleh Grande et al. (2011), Kouser et al. (2011), Saira et al. (2010), dan Soudani (2012) yang menyatakan penggunaan sistem informasi akuntansi tidak mampu meningkatkan profitabilitas dan kinerja individu. 
Berdasarkan teori ini menggambarkan bahwa efektivitas sistem informasi akuntansi sangat diperlukan karena dengan adanya sistem informasi akuntansi yang efektif maka kinerja individu akan dapat meningkat. Sistem informasi akuntansi yang efektif akan memberikan kesempatan bagi perusahaan untuk meningkatkan efisiensi dan efektivitas dalam pengambilan keputusan sehingga memungkinkan perusahaan untuk memperoleh keunggulan bersaing dibandingkan dengan kompetitornya (Faitira et al., 2012). Selain itu, sistem informasi yang digunakan secara tepat akan mampu meningkatkan kinerja individu dan organisasi (Gupta et al., 2007). Kristiani (2013) menyatakan bahwa efektivitas sistem informasi akuntansi berpengaruh positif dan signifikan terhadap kinerja karyawan. Sejalan dengan hasil penelitian dari Marlinawati \& Suaryana (2013), dan Suratini et al. (2015) yang menyatakan bahwa efektivitas sistem informasi akuntansi berpengaruh positif dan signifikan terhadap kinerja individu dan karyawan. Oleh karena itu, efektifnya sistem informasi akuntansi yang dimiliki sebuah organisasi maka akan mampu meningkatkan kinerja karyawan dalam organisasi tersebut. Berdasarkan uraian tersebut, maka dapat dirumuskan hipotesis sebagai berikut.

$\mathrm{H}_{1}$ : Efektivitas sistem informasi akuntansi berpengaruh positif pada kinerja karyawan.

Robbins \& Judge (2011) bawasanya dalam kenyataannya, salah satu kajian budaya organisasi mengemukakan bahwa para karyawan diperusahaan yang budayanya kuat lebih komitmen pada perusahaan mereka daripada karyawan di perusahaan yang budayanya lemah. Brahmasari \& Siregar (2009) menyatakan bahwa budaya organisasi berpengaruh positif terhadap kinerja karyawan. Pernyataan ini didukung oleh Arimbawa \& Dewi (2013), dan Wanjiku \& Lumwagi (2014) yang menyatakan bahwa variabel budaya organisasi berpengaruh positif signifikan terhadap kinerja karyawan. Perusahaan dengan budaya kuat juga akan menggunakan usaha-usaha perekrutan dan praktek sosialisasi mereka untuk membina komitmen karyawan. Hal ini membuktikan semakin banyak yang mengemukakan bahwa budaya kuat berkaitan dengan kinerja organisasi yang tinggi. Berdasarkan pemikiran diatas, hipotesis yang dapat diajukan dalam penelitian ini adalah sebagai berikut.

$\mathrm{H}_{2}$ : Budaya Organisasi berpengaruh positif terhadap Kinerja Karyawan.

\section{METODE PENELITIAN}

Penelitian menggunakan pendekatan kuantitatif berbentuk asosiatif. Penelitian dilakukan di LPD Kecamatan Tegalalang. Pemilihan LPDSe-Kecamatan Tegalalang karena ditemukan adanya kenaikan aset di LPD Se-Kecamatan Tegalalang setiap tahunnya. Obyek penelitian ini adalah Pengaruh Efektivitas Sistem Informasi Akuntansi dan Budaya Organisasi Pada kinerja karyawan di LPD Se-Kecamatan Tegalalang. Populasi yang digunakan dalam penelitian ini berjumlah 287 orang pada 41 LPD Se-Kecamatan Tegalalang. Metode penentuan sampel dilakukan dengan teknik purposive sampling, dan mendapatkan jumlah sampel sebanyak 41 LPD. Dari jumlah sampel diatas, maka responden ditentukan sebanyak 3 orang setiap LPD yaitu petugas pembukuan, kasir dan petugas tabungan. Dihitung dari jumlah sampel dan responden, maka didapatkan jumlah total responden sebanyak 123 orang dari jumlah total 
pegawai LPD Se-Keamatan Tegalalang sebanyak 287 orang. Teknik analisis data yang digunakan adalah analisis statistic deskriptif dan Analisis regresi linier berganda menggunakan SPSS.

\section{HASIL DAN PEMBAHASAN}

Statistik deskriptif digunakan untuk memberikan gambaran atau deskriptif suatu data yang dilihat dari nilai rata-rata (mean), nilai minimum, nilai maksimum, dan nilai dari data penelitian. Hasil dari pengujian statistik deskriptif dari masing-masing variabel penelitian disajikan pada Tabel 2 .

Tabel 2. Hasil Uji Statistik Deskriptif

\begin{tabular}{lccccc}
\hline \multicolumn{1}{c}{ Variabel } & N & $\begin{array}{c}\text { Nilai } \\
\text { Minimum }\end{array}$ & $\begin{array}{c}\text { Nilai } \\
\text { Maksimum }\end{array}$ & $\begin{array}{c}\text { Rata- } \\
\text { Rata }\end{array}$ & $\begin{array}{c}\text { Standar } \\
\text { Deviasi }\end{array}$ \\
\hline Efektivitas sistem informasi & & & & & \\
akuntansi & 121 & 14,00 & 28,00 & 24,13 & 3,038 \\
Budaya organisasi & 121 & 19,00 & 32,00 & 25,80 & 2,883 \\
Kinerja karyawan & 121 & 39,00 & 64,00 & 52,40 & 5,030 \\
\hline
\end{tabular}

Sumber: Data Penelitian, 2020

Berdasarkan Tabel 2, variabel efektivitas sistem informasi akuntansi memiliki nilai minimum sebesar 14,00 dan nilai maksimum sebesar 28,00, dengan nilai rata-rata sebesar 24,13. Nilai rata-rata tersebut memiliki kecenderungan mendekati nilai maksimum yang artinya efektivitas sistem informasi akuntansi yang dimiliki LPD Se-Kecamatan Tegalalang adalah efektif. Nilai standar deviasi pada variabel efektivitas sistem informasi akuntansi adalah sebesar 3,038, nilai tersebut lebih rendah dibandingkan nilai rata-ratanya. Hal ini menunjukkan data penelitian bersifat homogen sehingga dapat dikatakan bahwa persepsi yang dirasakan oleh karyawan LPD Se-Kecamatan Tegalalang atas efektivitas sistem informasi akuntansi adalah tinggi.

Variabel budaya organisasi memiliki nilai minimum sebesar 19,00 dan nilai maksimum sebesar 32,00, dengan nilai rata-rata sebesar 25,80. Nilai rata-rata tersebut memiliki kecenderungan mendekati nilai maksimum yang artinya budaya organisasi yang dimiliki LPD Se-Kecamatan Tegalalang adalah tinggi. Nilai standar deviasi pada variabel budaya organisasi adalah sebesar 2,883, nilai tersebut lebih rendah dibandingkan nilai rata-ratanya. Hal ini menunjukkan bahwa data penelitian bersifat homogen sehingga dapat dikatakan bahwa persepsi yang dirasakan oleh karyawan LPD Se-Kecamatan Tegalalang atas efektivitas sistem informasi akuntansi adalah tinggi.

Variabel kinerja karyawan memiliki nilai minimum sebesar 39,00 dan nilai maksimum sebesar 64,00 , dengan nilai rata-rata sebesar 52,40. Nilai rata-rata tersebut memiliki kecenderungan mendekati nilai maksimum yang artinya kinerja karyawan pada LPD Se-Kecamatan Tegalalang adalah tinggi. Nilai standar deviasi pada variabel kinerja karyawan adalah sebesar 5,030, nilai tersebut lebih rendah dibandingkan nilai rata-ratanya. Hal ini menunjukkan bahwa data penelitian bersifat homogen sehingga dapat dikatakan bahwa persepsi yang dirasakan oleh karyawan LPD Se-Kecamatan Tegalalang atas efektivitas sistem informasi akuntansi adalah tinggi. 
Tabel 3. Hasil Uji Analisis Regresi Linear Berganda

\begin{tabular}{|c|c|c|c|c|c|}
\hline \multirow[t]{2}{*}{ Variabel } & \multicolumn{2}{|c|}{$\begin{array}{c}\text { Unstandadized } \\
\text { Coefficient }\end{array}$} & \multirow{2}{*}{$\begin{array}{c}\text { Standardized } \\
\text { Coefficient }\end{array}$} & \multirow[t]{2}{*}{$\mathrm{t}$} & \multirow[t]{2}{*}{ Sig } \\
\hline & B & Std. Error & & & \\
\hline Constant & 13,951 & 3,473 & & 4,017 & 0,000 \\
\hline Efektivitas Sistem & & & & & \\
\hline Informasi Akuntansi & 0,223 & 0,100 & 0,135 & 2,237 & 0,027 \\
\hline Budaya Organisasi & 1,282 & 0,105 & 0,735 & 12,204 & 0,000 \\
\hline Adjusted $R_{\text {square }}$ & 0,568 & & & & \\
\hline$F_{\text {hitung }}$ & 80,023 & & & & \\
\hline Sig. F Fitung & 0,000 & & & & \\
\hline
\end{tabular}

Berdasarkan hasil analisis regresi linear berganda seperti yang disajikan pada Tabel 3, maka dapat dibuat persamaan regresi sebagai berikut.

$$
Y=13,951+0,223 X_{1}+1,282 X_{2}
$$

Dari persamaan tersebut diketahui bahwa nilai konstanta (a) menunjukkan nilai sebesar 13,951 . Nilai tersebut memiliki arti bahwa apabila tidak terdapat pengaruh dari efektivitas sistem informasi akuntansi dan budaya organisasi, maka variabel kinerja karyawan (Y) pada LPD Se-Kecamatan Tegalalang bernilai sebesar 13,951.

Tabel 4. Hasil Uji Analisis Koefisien Determinasi Masing-Masing Variabel

\begin{tabular}{lccc}
\hline \multicolumn{1}{c}{ Model Term } & Coefficient & Sig & Importance \\
\hline Intercept & 13,788 &, 000 & \\
Budaya Organisasi & 1,280 &, 000 & 0,969 \\
$\begin{array}{l}\text { Efektivitas Sistem Informasi } \\
\text { Akuntansi }\end{array}$ & 0,231 &, 033 & 0,031 \\
\hline
\end{tabular}

Sumber: Data Penelitian, 2020

Koefisien regresi variabel efektivitas sistem informasi akuntansi $\left(X_{1}\right)$ memiliki nilai sebesar 0,223 . Hal ini berarti bahwa apabila variabel efektivitas sistem informasi akuntansi $\left(\mathrm{X}_{1}\right)$ meningkat, maka akan mengakibatkan peningkatan pada kinerja karyawan dengan asumsi variabel bebas lainnya konstan. Koefisien regresi variabel budaya organisasi $\left(X_{2}\right)$ memiliki nilai sebesar 1,282. Hal ini berarti bahwa apabila variabel budaya organisasi $\left(X_{2}\right)$ meningkat, maka akan mengakibatkan peningkatan pada kinerja karyawan dengan asumsi variabel bebas lainnya konstan.

Berdasarkan Tabel 3, menunjukkan bahwa nilai Adjusted R Square sebesar 0,568 atau 56,8 persen, dan dijelaskan pada Table 4. bahwa pengaruh variabel Efektivitas Sistem Informasi Akuntansi pada kinerja karyawan sebesar 3,1 persen dan Budaya Organisasi pada kinerja karyawan sebesar 96,7 persen dengan total 100 persen dari 56,8 persen. Hal ini mengindikasikan bahwa pemanfaatan Sistem Informasi Akuntansi dan Budaya Organisasi mampu menjelaskan variabel kinerja karyawan sebesar 56,8 persen, sedangkan sisanya sebesar 43,2 persen dijelaskan oleh faktor lain yang tidak dimasukkan dalam model penelitian ini.

Berdasarkan Tabel 3, dapat dilihat bahwa nilai Fhitung yang diperoleh ialah sebesar 80,023 dengan nilai signifikansi sebesar 0,000 lebih kecil dari 0,05. Hal ini menunjukkan bahwa efektivitas sistem informasi akuntansi dan budaya 
organisasi dapat memprediksi atau menjelaskan kinerja karyawan pada LPD SeKecamatan Tegalalang, sehingga dapat disimpulkan bahwa model dalam penelitian ini layak untuk digunakan

Hipotesis pertama $\left(\mathrm{H}_{1}\right)$ dari penelitian ini menyatakan bahwa semakin efektifnya sistem informasi akuntansi yang dimiliki sebuah organisasi maka akan mampu meningkatkan kinerja karyawan dalam organisasi tersebut. Setelah dilakukannya pengujian, hasil penelitian menunjukkan bahwa nilai koefisien regresi positif sebesar 0,223 dengan nilai signifikansi 0,027 yang lebih kecil dari 0,05 . Hasil ini menunjukkan bahwa variabel efektifitas sistem informasi akuntansi berpengaruh positif pada kinerja karyawan, maka hipotesis pertama $\left(\mathrm{H}_{1}\right)$ diterima. Hal ini berarti semakin efektifnya sistem informasi akuntansi, maka akan mampu meningkatkan kinerja karyawan yang dimiliki oleh LPD SeKecamatan Tegalalang. Hal ini sejalan Teori Technology Acceptance Model (TAM) yang menjelaskan bahwa efektivitas sistem informasi akuntansi sangat diperlukan karena dengan adanya sistem informasi akuntansi yang efektif maka kinerja individu akan dapat meningkat. Sistem informasi akuntansi yang efektif akan memberikan kesempatan bagi perusahaan untuk meningkatkan efisiensi dan efektivitas dalam pengambilan keputusan sehingga memungkinkan perusahaan untuk memperoleh keunggulan bersaing dibandingkan dengan kompetitornya.

Hasil penelitian ini sejalan dengan penelitian Kristiani (2013) menyatakan bahwa efektivitas sistem informasi akuntansi berpengaruh positif dan signifikan terhadap kinerja karyawan. Sejalan dengan hasil penelitian dari Marlinawati \& Suaryana (2013), dan Suratini et al. (2015) yang menyatakan bahwa efektivitas sistem informasi akuntansi berpengaruh positif dan signifikan terhadap kinerja individu dan karyawan. LPD yang memiliki sistem informasi akuntansi yang efektif akan mampu meningkatkan kinerja karyawan yang dimilikinya.

Hipotesis kedua $\left(\mathrm{H}_{2}\right)$ dari penelitian ini menyatakan bahwa semakin kuat budaya organisasi, maka karyawan lebih berkomitmen dalam memajukan organisasi. Setelah dilakukannya pengujian, hasil penelitian menunjukkan bahwa nilai koefisien regresi positif sebesar 1,282 dengan nilai signifikansi 0,000 yang lebih kecil dari 0,05. Hasil ini menunjukkan bahwa variabel budaya organisasi berpengaruh positif pada kinerja karyawan, maka hipotesis kedua $\left(\mathrm{H}_{2}\right)$ diterima. Hal ini berarti semakin kuat budaya organisasi yang dimiliki oleh LPD Se-Kecamatan Tegalalang, maka karyawannya akan lebih berkomitmen dalam memajukan LPD. Budaya organisasi yang kuat berkaitan dengan kinerja karyawan yang unggul, karena budaya organisasi yang kuat menciptakan suatu tingkat motivasi karyawan yang mendorong anggota organisasi untuk berkomitmen dalam memajukan organisasi.

Hasil penelitian ini sejalan dengan penelitian Brahmasari \& Siregar (2009) menyatakan bahwa budaya organisasi berpengaruh positif terhadap kinerja karyawan. Sejalan juga dengan penelitian Arimbawa \& Dewi (2013) dan Wanjiku \& Lumwagi (2014) yang menyatakan bahwa variabel budaya organisasi berpengaruh positif signifikan terhadap kinerja karyawan. Hal ini dapat diartikan juga bahwa LPD Se-Kecamatan Tegalalang dengan budaya yang kuat juga akan menggunakan usaha-usaha perekrutan dan praktek sosialisasi mereka untuk membina komitmen karyawan dalam memajukan LPD. 


\section{SIMPULAN}

Berdasarkan pemaparan dapat dinyatakan bahwa efektivitas sistem informasi akuntansi berpengaruh positif pada kinerja karyawan. Hal ini berarti bahwa semakin efektif sistem informasi akuntansi yang dimiliki LPD Se-Kecamatan Tegalalang maka semakin baik kinerja karyawan di LPD Se-Kecamatan Tegalalang. Budaya organisasi berpengaruh positif pada kinerja karyawan. Hal ini berarti bahwa semakin baik budaya organisasi yang dimiliki LPD SeKecamatan Tegalalang maka semakin baik kinerja karyawan di LPD SeKecamatan Tegalalang.

Berdasarkan hasil penelitian yang telah dilakukan, maka saran yang dapat diberikan yakni LPD perlu meningkatkan pemahaman akan sistem informasi akuntansi yang digunakan agar karyawan dapat mudah menjalankan tugasnya. LPD perlu meningkatkan sistem keamanan pada program yang digunakan untuk menjaga kerahasiaan informasi. Karyawan LPD perlu meningkatkan pengetahuan sesuai dengan bidangnya agar mampu menyelesaikan permasalahan yang timbul dalam LPD. Karyawan LPD perlu mengembangkan pengetahuan terbaru terkait pengembangan LPD dan sesuai dengan pedoman atau aturan yang berlaku agar dalam pelaksanaan tugasnya efektif dan efisien.

Berdasarkan pemaparan di atas, maka dalam penelitian ini masih terdapat beberapa keterbatasan. Pertama, sampel yang dipakai perlu ditingkatkan. Hal tersebut dilakukan bahwa agar hasil yang didapat dapat menggambarkan keadaan dilapangan secara holistik. Kedua, kontruksi variabel yang digunakan pada model penelitian sederhana. Hal tersebut kedepannya dapat ditanggulangi dengan cara menambah kontruksi variabel dalam bentuk variabel mediasi maupun moderasi.

\section{REFERENSI}

Afnita, M., Muis, M., \& Umar, F. (2014). Pengaruh Budaya Organisasi dan Kompensasi terhadap Kinerja Karyawan di BPJS Ketenagakerjaan kantor pusat. Jurnal Analisis, 3(2), 172-179.

Al-Eqab, M., \& Adel, D. (2013). The impact of IT sophistications on the perceived usefulness of accounting information characteristics among Jordanian listed companies. International Journal of Business and Social Science, 4(3), 145-155.

Apriada, K., \& Suardikha, M. S. (2016). Pengaruh Struktur Kepemilikan Saham, Struktur Modal Dan Profitabilitas Pada Nilai Perusahaan. Jurnal Ekonomi Dan Bisnis Universitas Udayana, 5(2), 201-218.

Arianty, N. (2014). Pengaruh Budaya Organisasi Terhadap Kinerja Pegawai. Jurnal Manajemen E Bisnis, 14(2), 1693-7619.

Arimbawa, K., \& Dewi, A. (2013). Pengaruh Budaya Organisasi, Gaya Kepemimpinan, Dan Motivasi Kerja Terhadap Kinerja Karyawan Pada Hotel Jimbaran Puri Bali. E-Jurnal Manajemen Universitas Udayana, 2(12), 1693-1710.

Ariyanto, D., Dewi, A. A., \& Made Gilang Jhuniantara, I. (2020). Perceived learning assistance and perceived community building assistance: Study on e-learning system. Systematic Reviews in Pharmacy. https://doi.org/10.31838/srp.2020.12.53

Brahmasari, I. A., \& Siregar, P. (2009). Pengaruh Budaya Organisai, 
Kepemimpinan Situasional dan Pola Komunikasi terhadap Disiplin Kerja dan kinerja karyawan pada PT. Central Proteinaprima Tbk. Jurnal Aplikasi Manajemen, 7(1), 238-250.

Candraningrat, I. R., Abundanti, N., Mujiati, N. W., Erlangga, R., \& Jhuniantara, I. M. G. (2020). The role of financial technology on development of MSMEs. Accounting. https://doi.org/10.5267/j.ac.2020.9.014

Faitira, E., Joseph, M., Gutu, K. G., \& Manuere. (2012). Evaluation of factors influencing adoption of accounting information system by small to medium enterprises in Chinhoyi. Interdisciplinary Journal of Contemporary Research In Business, 4(6), 1121-1146.

Grande, E. U., Estébanez, R. P., \& Colomina, C. M. (2011). The impact of accounting information systems (AIS) on performance measures: Empirical evidence in spanish SMEs. International Journal of Digital Accounting Research, 11(February), 25-43. https:// doi.org/10.4192/1577-8517-v11_2

Gupta, M. P., Kanungo, S., Kumar, R., \& Sahu, G. P. (2007). A study of information technology effectiveness in select government organizations in India. Vikalpa, 32(2), 7-21. https:/ / doi.org/10.1177/0256090920070202

Ivancevich, J. M. (2007). Perilaku dan Manajemen Organisasi. Erlangga.

Kelton, W. D., Sadowski, R. P., \& Sturrock, D. T. (2007). Simulation, with Arena, Fourth Edition. McGraw-Hill.

Kouser, R., Awan, A., Gul-e-Rana, \& Shahzad, F. A. (2011). Firm size, leverage and profitability: Overriding impact of Accounting Information System. Business \& Management Review, 1(10), 58-64.

Kristiani, W. (2013). Analisis Pengaruh Efektivitas Teknologi Sistem Informasi Akuntansi Terhadap Kinerja Individual Pegawai Pt. Kim Eng Sekuritas Indonesia. Journal of Chemical Information and Modeling.

Kusumadmo, E. (2013). Manajemen Strategik Pengetahuan. Cahaya Atma Pustaka.

Larasdiputra, G. D., \& Suryanawa, I. K. (2014). Penerapan Sistem Informasi Akuntansi Pada Bank Perkreditan Rakyat Sari Jaya Sedana Klungkung. Jurnal Akuntansi Universitas Udayana, 7(3), 791-805.

Marlinawati, N. M. A., \& Suaryana, I. G. N. A. (2013). Pengaruh Penggunaan Teknologi Informasi, Efektivitas Sistem Informasi Akuntansi, Kepercayaan Atas Sistem Informasi Akuntansi, dan Kesesuaian Tugas pada Kinerja Karyawan Lembaga Perkreditan Desa di Kabupaten Badung. E-Jurnal Akuntansi, 2(2).

Mercika, N., \& Jati, I. (2015). Kemudahan Penggunaan Sistem Sebagai Pemoderasi Pengaruh Efektivitas Sistem Informasi Akuntansi Pada Kinerja. E-Jurnal Akuntansi.

Nwokeji, E. N. A. (2012). Repositioning Accounting Information System Through Effective Data Quality Management: A Framework For Reducing Costs And Improving Performance. International Journal of Scientific $\mathcal{E}$ Technology Research, 1(10).

Puja, G., \& Suardikha, I. (2013). Keahlian Pemakai Komputer Dan Kenyamanan Fisik Dan Tingkat Efektivitas Sistem Informasi Akuntansi Terhadap Kinerja Karyawan. E-Jurnal Akuntansi, 5(2), 360-380.

Puji Astuti, N., \& Dharmadiaksa, I. (2014). Pengaruh Efektivitas Penerapan Sistem Informasi Akuntansi, Pemanfaatan dan Kesesuaian Tugas dengan 
Teknologi Informasi pada Kinerja Karyawan. E-Jurnal Akuntansi.

Robbins, S. P., \& Judge, T. . (2011). Perilaku Organisasi (12th ed.). Salemba Empat.

Saira, K., Zariyawati, M. A., \& Annuar, M. N. (2010). Information System and Firms' Performance: The Case of Malaysian Small Medium Enterprises. International Business Research, 3(4), 33. https://doi.org/10.5539/ibr.v3n4p28

Shahzad, F., Superior, T., \& Lahore, C. (2014). Impact of organizational culture on employees' job performance: An empirical study of software houses in Pakistan. International Journal of Commerce and Management, 24(3), 219-227. https://doi.org/10.1108/IJCoMA-07-2012-0046

Soedjono. (2005). Pengaruh Budaya Organisasi Terhadap Kinerja Organisasi Dan Kepuasan Kerja Karyawan Pada Terminal Penumpang Umum Di Surabaya. Jurnal Manajemen Dan Wirausaha, 7(1), 22-47. https://doi.org/10.9744/jmk.7.1.pp.22-47

Soudani, S. N. (2012). The Usefulness of an Accounting Information System for Effective Organizational Performance. International Journal of Economics and Finance, 4(5), 136-145. https:/ / doi.org/10.5539/ijef.v4n5p136

Suartana, I. W. (2009). Arsitektur Pengelolaan Risiko pada LPD (Lembaga Perkreditan Desa). Udayana University Press.

Suratini, N. P. E. S., Sinarwati, N. K., \& Atmadja, A. W. T. (2015). Penggunaan Teknologi Informasi Akuntansi terhadap Kinerja Individual Pada PT . Bank Pembangunan Daerah e-Journal S1 Ak Universitas Pendidikan Ganesha. EJournal S1 Ak Universitas Pendidikan Ganesha.

Tanuwibowo, J. C., \& Sutanto, E. M. (2014). Hubungan Budaya Organisasi dan Komitmen Organisasional pada Kinerja Karyawan. TRIKONOMIKA. https://doi.org/10.23969/trikonomika.v13i2.609

Tokic, M., Spanja, M., Tokic, I., \& Blazevic, I. (2011). Functional Structure Of Entrepreneurial Accounting Information Systems. Annals of the Faculty of Engineering Hunedoara.

Wanjiku, N. A., \& Lumwagi, N. (2014). Effect of Organisation Culture on Employee Performance in Non Govermental Organizations. International Journal of Scientific and Research Publications.

Yamit, Z. (2003). Manajemen Produksi dan Operasi. Ekosinia. 